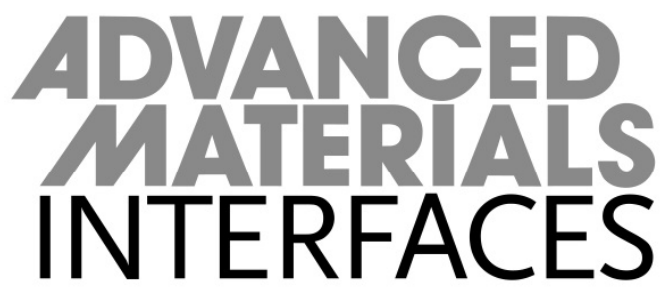

Postfach 101161 69451 Weinheim

Germany

WILEY-VCH

Courier services:

Boschstraße 12

69469 Weinheim

Germany

Tel.: (+49) 6201606235

Fax: (+49) 6201606500

E-mail: advmatinterfaces@wiley.com

Dear Author,

Please correct your galley proofs carefully and return them no more than four days after the page proofs have been received.

Please limit corrections to errors already in the text; cost incurred for any further changes or additions will be charged to the author, unless such changes have been agreed upon by the editor.

The editors reserve the right to publish your article without your corrections if the proofs do not arrive in time.

Note that the author is liable for damages arising from incorrect statements, including misprints.

Please note any queries that require your attention. These are indicated with a $Q$ in the PDF and a question at the end of the document.

Reprints may be ordered by filling out the accompanying form.

Return the reprint order form by fax or by e-mail with the corrected proofs, to WileyVCH : advmatinterfaces@wiley.com
To avoid commonly occurring errors, please ensure that the following important items are correct in your proofs (please note that once your article is published online, no further corrections can be made):

- Names of all authors present and spelled correctly

- Titles of authors correct (Prof. or Dr. only: please note, Prof. Dr. is not used in the journals)

- Addresses and postcodes correct

- E-mail address of corresponding author correct (current email address)

- Funding bodies included and grant numbers accurate

- Title of article OK

- All figures included

- Equations correct (symbols and sub/superscripts)

Corrections should be made directly in the PDF file using the PDF annotation tools. If you have questions about this, please contact the editorial office. The corrected PDF and any accompanying files should be uploaded to the journal's Editorial Manager site. 


\section{Author Query Form}

Journal

ADMI

Article

admi201901942

Dear Author,

During the copyediting of your manuscript the following queries arose.

Please refer to the query reference callout numbers in the page proofs and respond to each by marking the necessary comments using the PDF annotation tools.

Please remember illegible or unclear comments and corrections may delay publication.

Many thanks for your assistance.

\begin{tabular}{|c|c|c|}
\hline Query No. & Description & Remarks \\
\hline Q-OO & $\begin{array}{l}\text { Open access publication of this work is possible via Wiley OnlineOpen. Information about } \\
\text { this is available at: https://authorservices.wiley.com/author-resources/Journal-Authors/ } \\
\text { licensing-open-access/open-access/onlineopen.html. } \\
\text { The cost of publishing your manuscript OnlineOpen may be covered by one of Wiley's } \\
\text { national agreements. To find out more, visit https://authorservices.wiley.com/author- } \\
\text { resources/Journal-Authors/open-access/affiliation-policies-payments/index.html. } \\
\text { Note that eligibility for fee coverage is determined by the affiliation of the primary } \\
\text { corresponding author designated at submission. Please log in to your Wiley Author } \\
\text { Services account at https://authorservices.wiley.com/ and confirm your affiliation to see } \\
\text { if you are eligible. } \\
\text { Instructions for placing an OnlineOpen order can be found at: https://authorservices. } \\
\text { wiley.com/author-resources/Journal-Authors/open-access/how-to-order-onlineopen.html. } \\
\text { To publish your article open access, please complete the order process before completing } \\
\text { your proof corrections. }\end{array}$ & \\
\hline Q1 & $\begin{array}{l}\text { Please confirm that forenames/given names (blue) and surnames/family names } \\
\text { (vermilion) have been identified correctly. }\end{array}$ & \\
\hline Q2 & Please verify the updated city, postal code, and country in affiliation 1. & \\
\hline Q3 & $\begin{array}{l}\text { Please provide the highest academic title (either Dr. or Prof.) for all authors, where } \\
\text { applicable. }\end{array}$ & \\
\hline Q4 & $\begin{array}{l}\text { Please shorten Abstract text to a maximum of } 200 \text { words. All abbreviations should be } \\
\text { defined. }\end{array}$ & \\
\hline Q5 & $\begin{array}{l}\text { Please define PBS, at its first appearance in the abstract, text and table of contents, } \\
\text { respectively. }\end{array}$ & \\
\hline Q6 & $\begin{array}{l}\text { As per style Section } 2 \text { 'Experimental Section' has been changed to Section } 4 \text { 'Experimental } \\
\text { Section' and moved to the end of the text. Also, we have renumbered/changed subsequent } \\
\text { section headings. Please verify. }\end{array}$ & \\
\hline Q7 & $\begin{array}{l}\text { Please define EVOS, at its first appearance in the abstract, text and table of contents, } \\
\text { respectively. }\end{array}$ & \\
\hline Q8 & $\begin{array}{l}\text { Please verify the inserted text from the Author Contributions section to the } \\
\text { Acknowledgements. }\end{array}$ & \\
\hline Q9 & $\begin{array}{l}\text { As per style, The authors' contribution statement has been moved to the Author } \\
\text { Contributions section. }\end{array}$ & \\
\hline Q10 & Please verify the updated page number in ref. (30). & \\
\hline
\end{tabular}

Please confirm that Funding Information has been identified correctly.

Please confirm that the funding sponsor list below was correctly extracted from your article: that it includes all funders and that the text has been matched to the correct FundRef Registry organization names. If a name was not found in the FundRef registry, it may not be the canonical name form, it may be a program name rather than an organization name, or it may be an organization not yet included in FundRef Registry. If you know of another name form or a parent organization name for a "not found" item on this list below, please share that information.

\begin{tabular}{|l|l|}
\hline FundRef Name & FundRef Organization Name \\
\hline H2020 European Research Council & H2020 European Research Council \\
\hline European Research Council & European Research Council \\
\hline
\end{tabular}




\section{FULL PAPERS}

V. M. Moreno, E. Álvarez,

I. Izquierdo-Barba, A. Baeza,*

J. Serrano-Lopez,

M. Vallet-Regí*

1901942

Bacteria as Nanoparticles Carrier for Enhancing Penetration in a Tumoral Matrix Model

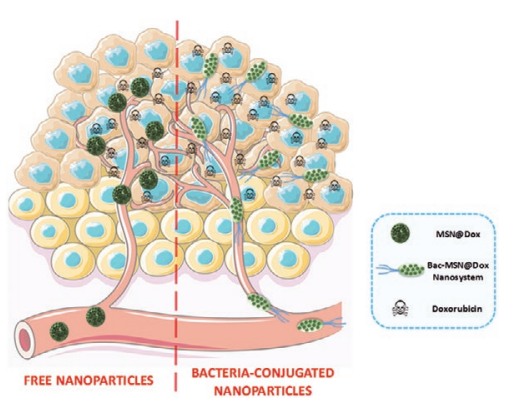

Bacteria-assisted mesoporous silica nanoparticles achieve high penetration in 3 tumor matrix models. The motility of bacteria allows the delivery of cytotoxic 5 drugs into deep areas of the malignancy, 6 improving their therapeutic effect in comparison with free nanoparticles.

6 6
7 


\title{
Bacteria as Nanoparticles Carrier for Enhancing Penetration in a Tumoral Matrix Model
}

\author{
Víctor M. Moreno, Elena Álvarez, Isabel Izquierdo-Barba, Alejandro Baeza,* 6 \\ Juana Serrano-Lopez, and María Vallet-Regi* $\quad 8$ \\ Juana Serrano-Lopez, and Maria Vallet-Regitar 9
}

One of the major concerns in the application of nanocarriers in oncology is their scarce penetration capacity in tumoral tissues, which drastically compromises the effectivity. Living organisms as cells and bacteria present the capacity to navigate autonomously following chemical gradients being able to penetrate deeply into dense tissues. In the recent years, the possibility to employ these organisms for the transportation of therapeutic agents and nanocarriers attached on their membrane or engulfed in their inner space have received huge attention. Herein, based on this principle, a new approach to deliver drug loaded nanoparticles achieving high penetration in tumoral matrices is presented. In this case, Escherichia coli (E. coli) bacteria wall is decorated with azide groups, whereas alkyne-strained groups are incorporated on the surface of mesoporous silica nanoparticles loaded with a potent cytotoxic compound, doxorubicin. Both functional groups form stable triazole bonds by click-type reaction allowing the covalent grafting of nanoparticles on living bacteria. Thus, the motility and penetration capacity of bacteria, which carried nanoparticles are evaluated in a 3D tumoral matrix model composed by a dense collagen extracellular matrix with HT1080 human fibrosarcome cells embedded. The results confirmed that bacteria are able to transport the nanoparticles crossing a thick collagen layer being able to destroy almost $80 \%$ of the tumoral cells located underneath. These findings envision a powerful strategy in nanomedicine applied for cancer treatment by allowing a homogeneous distribution of therapeutic agents in the malignancy.

\section{Introduction}

Conventional antitumoral chemotherapy is based on the administration of highly toxic drugs, which provoke the apparition of their surface. Unfortunately, despite the excellent performance 41 of different nanocarriers in in vitro cell cultures and even in 42 some in vivo models this behavior is not achieved in real 43 clinical situations and only a few nanosystems have reached 44

can be found under https://doi.org/10.1002/admi.201901942.

$\begin{array}{ll}\text { A. Baeza } & 47 \\ \text { Dpto. Materiales y Producción Aeroespacial } & 48 \\ \text { ETSI Aeronáutica y del Espacio } & 49 \\ \text { Universidad Politécnica de Madrid } & 50 \\ \text { Madrid 28040, Spain } & 51 \\ \text { E-mail: alejandro.baeza@upm.es } & 52 \\ \text { J. Serrano-Lopez } & 53 \\ \text { Experimental Hematology Lab } & 54 \\ \text { IIS-Fundación Jiménez Díaz } & 55 \\ \text { UAM } & 56 \\ \text { Madrid 28040, Spain } & 57 \\ & 58 \\ & 59\end{array}$ 11 13
V. M. Moreno, E. Álvarez, I. Izquierdo-Barba, M. Vallet-Regí

Universidad Complutense de Madrid

Instituto de Investigación Sanitaria

V. M. Moreno, E. Álvarez, I. Izquierdo-Barba, M. Vallet-Regí

CIBER de Bioingeniería

Biomateriales y Nanomedicina

DOI: 10.1002/admi.201901942

Adv. Mater. Interfaces 2020, 1901942 
1 the market. ${ }^{[1]}$ The reasons of this disappointing outcome are

2 varied. One of them is that tumoral tissues present a dense 3 extracellular matrix, which hampers the particle penetration 4 constraining the therapeutic effect of the nanocarrier only on 5 the tumor periphery. ${ }^{[12]}$ The targeting capacity of the nanocar6 riers takes place in the nanoscale. Therefore, a proper distribu7 tion of the nanocarriers within the malignancy is compulsory 8 to treat the whole tumoral cell population. This scenario is 9 not present when the particles are blocked in the tumor mar10 gins. ${ }^{[13]}$ Some research groups have addressed this limitation 11 anchoring proteolytic enzymes on the nanoparticle surface in 12 order to digest the extracellular matrix improving the particle 13 diffusion throughout the malignant tissue. ${ }^{[14,15]}$ Recently, our 14 research group have reported the use of stimuli-responsive 15 polymeric nanocapsules which release collagenase under the 16 mild acidic conditions present in the tumor environment. ${ }^{[16]}$ 17 These capsules were anchored on the surface of drug loaded 18 protocells functionalized with a specific antibody against lung 19 cancer cells, improving their penetration into tumoral tissue 20 and allowing the particle internalization into deep tumoral 21 cells. Other problem which strongly limits the therapeutic effi22 cacy of nanomedicines is the high interstitial pressure usually 23 present in solid tumors caused by their fast growing rate that 24 compresses the surrounding lymphatic vessels blocking the 25 tissue drainage. ${ }^{[17]}$ This pressure makes particle diffusion con26 siderably difficult. Finally, EPR effect is not generally present 27 in all solid tumors but it is limited to a few of them as Kaposi's 28 sarcoma, being only partially present or completely absent in 29 many of them. ${ }^{[18]}$ Even, EPR effect within the tumor vary during 30 the treatment.

31 In the last years, the use of living systems as carrier of 32 nanocarriers has been postulated to overcome these limita33 tions. ${ }^{[19]}$ The self-propelled and guiding capacity of cells ${ }^{[20]}$ 34 and bacteria ${ }^{[21]}$ allow them to penetrate living tissues regard-

35 less hydrodynamic considerations. Among them, the use of

36 bacteria as drug carriers has received huge attention in anti-

37 tumoral therapy due to their excellent motion capacities. ${ }^{[22]}$

38 Moreover, these tiny microorganisms are able to move toward

39 gradients in response to small changes in internal stimulus

40 (specific chemicals, temperature, or $\mathrm{pH}$ variations), or guided

41 by external stimulus (magnetic field). ${ }^{[23-27]}$ Thus, anaerobes

42 bacteria are able to colonize hypoxic regions into tumoral

43 tissues reaching inner zones of the malignancy, as has been

44 studied in vitro and in vivo. ${ }^{[28-30]}$ Herein, we report the use of

45 Escherichia coli (E. coli) as model of facultative anaerobic bac-

46 teria for the transportation of mesoporous silica nanoparticles

47 (MSN) loaded with a potent cytotoxic compound, doxorubicin

48 (Dox). In this work, MSN have been used as nanocarrier in

49 this work due to their excellent biocompatibility and lack of

50 toxicity as has been widely proved elsewhere. ${ }^{[31]}$ Bacteria wall

51 has been decorated with azide groups through the incorpo-

52 ration of an azide-functionalized aminoacid (azide- $D$-alanine)

53 to the culture media. ${ }^{[32]}$ This aminoacid was incorporated to

54 the bacteria wall through the normal bacteria metabolism

55 and the presence of azide groups on the outer bacteria sur-

56 face was employed for the covalent attachment of MSN dec-

57 orated with strained alkynes by the well-known cooper-free

58 azide-alkyne cycloaddition which is compatible with living

59 systems. According to these results, it is established that these modifications do not affect to the bacterial viability. ${ }^{[33,34]} 1$ Therefore, bacteria were able to transport them into deep 2 zones into a 3D tumoral matrix model composed by a dense collagen extracellular matrix with the HT1080 human fibrosarcome cells, as tumoral cell line model, embedded within their structure. The homogeneous MSN distribution allowed by the action of bacteria as carriers yielded a significant improvement in the therapeutic effect due to Dox release in comparison with free particles. This proof of concept opens the way to treat solid tumors employing this strategy using nonpathogenic bacteria. Therefore, it would be possible to utilize organisms as nanoparticle carriers capable to follow specific gradients within solid tumors as hypoxic zones or acidic environments improving the distribution of nanomedicines within the malignancy.

\section{Results and Discussion}

\subsection{Synthesis and Characterization of MSN-PEG-DBCO}

Fluorescent MSN were synthetized by covalently linking the fluorescent dye to the silica network following a modified Stöber method ${ }^{[15]}$ yielding monodisperse nanoparticles with an average diameter of $80-100 \mathrm{~nm}$ and a pore size of $2-3 \mathrm{~nm}$. The functionalization of MSN materials was carried out in several steps. First, MSN were functionalized with (3-triethoxysilyl)propylsuccinic anhydride (TESPSA) providing carboxylic groups on the particle surface (MSN-COOH), which allow to bind dibenzylcyclooctyne- $\mathrm{PEG}_{4}$-Amine (DBCO-PEG-NH $\mathrm{N}_{2}$ ) by amide formation via carbodiimide coupling to yield MSN-PEG-DBCO. $\mathrm{DBCO}$ is a biorthogonal group that allows the attachment of different biomolecules thanks to the specific reaction with azide derivatives yielding stable triazoles in mild conditions. ${ }^{[35]}$ The hydrophilic polyethylene glycol (PEG) spacer provides a large and flexible connection that minimizes steric hindrance in the ligation of MSN-DBCO to complementary azide-containing molecules and also avoids the aggregation of MSN by steric hindrance. ${ }^{[36]}$ Regarding MSNs degradation, our research group has previously reported that degradability of MSN depends on numerous factors, as nanoparticle diameter, pore type, and surface functionalization. ${ }^{[37]}$ This research work states that $200 \mathrm{~nm}$ MSNs dispersed in PBS are partially degraded after a few days in aqueous suspension but the structural integrity of the nanoparticle remains almost invariable for about a week. In addition, the degradation product leached in form of orthosilicic acid is harmless. Dynamic light scattering (DLS) measurements of the obtained MSN-PEG-DBCO revealed an average particle diameter of 91-105 $\mathrm{nm}$ (see Figure S1A, Supporting Information). Figure 1A displays the transmission electron microscopy (TEM) image corresponding to MSN-PEG-DBCO sample, showing a nearly hexagonal shape with an average diameter of $100 \mathrm{~nm}$ and monodispersed distribution.

Fourier transform infrared (FTIR) spectroscopy was employed to verify the successful functionalization with carboxylic groups and DBCO-PEG-NH$H_{2}$, respectively. For pristine MSN, the characteristic absorption bands of the tetrahedron silica structures at $1100 \mathrm{~cm}^{-1}$ ( $\mathrm{Si}-\mathrm{O}-\mathrm{Si}$ bending) and $800 \mathrm{~cm}^{-1}$ (Si-O stretching) were clearly observed. After the

\section{2} 3 4 5 6 7 

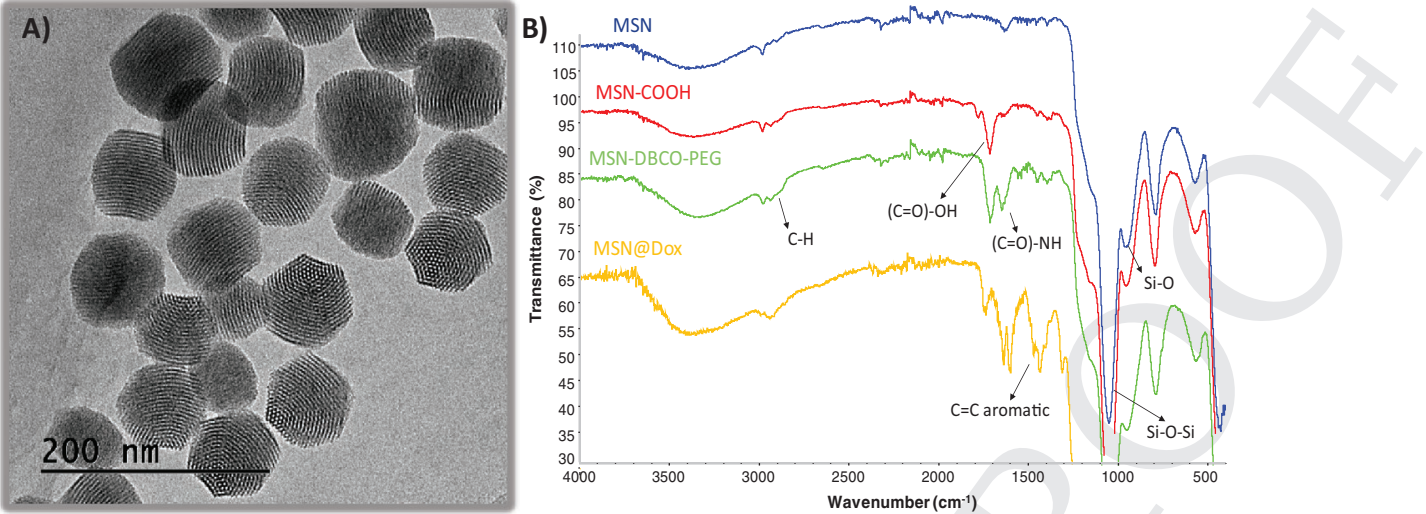

Figure 1. A) TEM micrography corresponding to MSN-PEG-DBCO sample. B) FTIR spectra corresponding to MSN, MSN-COOH, MSN-PEG-DBCO, 16 and MSN@Dox samples.

functionalization with TESPSA, the peaks corresponding to $\mathrm{C}(=\mathrm{O})-\mathrm{OH}$ stretching vibrations appeared at $\approx 1700 \mathrm{~cm}^{-1}$. Finally, the DBCO-PEG on the silica surface was confirmed by the apparition of the characteristic amide band at $\approx 1650 \mathrm{~cm}^{-1}$ $(\mathrm{N}-\mathrm{H}$ stretch) and a slight increase in $\mathrm{C}-\mathrm{H}$ alkane band $\left(2850-2950 \mathrm{~cm}^{-1}\right)$ (Figure 1B). The organic content of MSN materials was quantified by thermogravimetric analysis (TGA) measurements to follow the incorporation of the organic material (see Figure S1C, Supporting Information). TGA indicates a slight increase in the organic matter after each synthetic step, and $\mathrm{Z}$ potential analysis at neutral $\mathrm{pH}$ indicates an alteration in the surface charge from $-20 \mathrm{mV}$ in the case of naked MSN to $-24 \mathrm{mV}$ in MSN-PEG-DBCO. Finally, MSN-PEG-DBCO was incubated with a slight excess of TAMRA-Azide $(10 \mu \mathrm{L}$ of a $1 \mathrm{mg} \mathrm{mL}^{-1}$ solution) in order to evaluate the capacity of these functional groups to attach a biomolecule model, in this case TAMRA fluorophore. The particles which contained the strained alkyne on their surface showed 13-fold higher fluorescence than nonfunctionalized ones, confirming the presence on the nanoparticles surface of $\mathrm{DBCO}$ and its reactivity. The amount of DBCO present in the nanoparticles $(0.72 \mu \mathrm{g}$ DBCO-PEG-NH $\mathrm{H}_{2} / \mathrm{mg}$ MSN-PEG-DBCO) was determined from the TAMRA fluorescence obtained for MSN-PEG-DBCO (see Figure S2, Supporting Information).

\subsection{Attachment of MSN-PEG-DBCO to Bacteria (Bac-MSN)}

The attachment of a nanoparticle on the surface of a living cell requires the use of chemoselective reactions which can be carried out in mild conditions in the presence of the myriad of compounds that usually constitute the biological fluids. In the recent years, a vast arsenal of these types of reactions, encompassed within the term of bio-orthogonal chemistry, have been developed. ${ }^{[38]}$ Among them, cooper-free strain-promoted azide-alkyne cycloaddition is one of the most widely employed reactions with this purpose thanks to its exquisite selectivity, high yield, and absence of the toxicity caused by the metal which allow its use, even into complex organisms. ${ }^{[39]}$ The first step required for exploiting this chemistry to attach the nanoparticles on the bacteria surface is the incorporation of azide groups on their surface. This requirement was fulfilled 19 growing bacteria in a culture medium enriched with azide- 20 $D$-alanine. Bacteria incorporates this aminoacid in the struc- 21 ture of peptidoglycans of their cell wall and therefore, it places 22 the azide groups on the bacteria surface. The presence of 23 azide groups on the bacteria wall was evaluated adding DBCO- 24 TAMRA to the cell culture media. Bacteria which were previ- 25 ously incubated with azide- $D$-alanine exhibited a bright red 26 fluorescence by fluorescence microscopy, whereas bacteria that 27 were cultured without this amino acid did not incorporate the 28 fluorophore and therefore, fluorescence was not visible (see 29 Figure S3, Supporting Information). Once confirmed the pres- 30 ence of azide groups on the bacteria surface, the attachment 31 of MSN-PEG-DBCO was evaluated. Thus, azide-decorated bac- 32 teria cultures (O.D. $=0.25)$ were incubated in the presence of 33 different nanoparticle batches with increasing nanoparticle 34 concentrations for $1.5 \mathrm{~h}$ (Figures 2 and 3). After the incubation 35 time, the excess of nanoparticles was removed by washing/cen- 36 trifugation steps and the attachment of MSN on bacteria wall 37 was determined by flow cytometry analysis (FACS). Bacteria 38 without nanoparticles were used as control. To avoid bacteria 39 growing, each batch was incubated with Paraformaldehyde 40 $(3 \% \mathrm{w} / \mathrm{v})$ overnight previous to FACS analysis. For the detec- 41 tion of bacteria in the cytometry equipment, they were stained 42 with Propidium iodide (PI) as red fluorescence labeling. Nano- 43 particle attachment to bacteria was evaluated by measuring 44 the green fluorescence (due to FITC-labeled MSN) percentage 45 ratio obtained in the red-positive bacteria $(+,+$ fluorescence) 46 dot-plots histogram region (see Figures S4-S11, Supporting 47 Information). The results indicate that the highest attachment 48 rate was yielded by the concentration of $50 \mu \mathrm{g} \mathrm{MSN} \mathrm{mL}{ }^{-1} 49$ $(\approx 60 \%)$, whereas this amount was reduced when higher nano- 50 particle concentrations were employed, probably caused by 51 the formation of nanoparticle aggregates in these high con- 52 centrated suspensions, as shown in Figure 3. The presence of 53 nanoparticles on bacteria surface was confirmed by scanning 54 electron microscopy (SEM), which showed a homogeneous 55 distribution of nanoparticles in the bacteria wall comparing to 56 bacteria without nanoparticles (Figure 2) and demonstrating 57 that nanoparticles are present in the majority of bacteria (see 58 Figure S12, Supporting Information).

\section{6} , (1) . . 

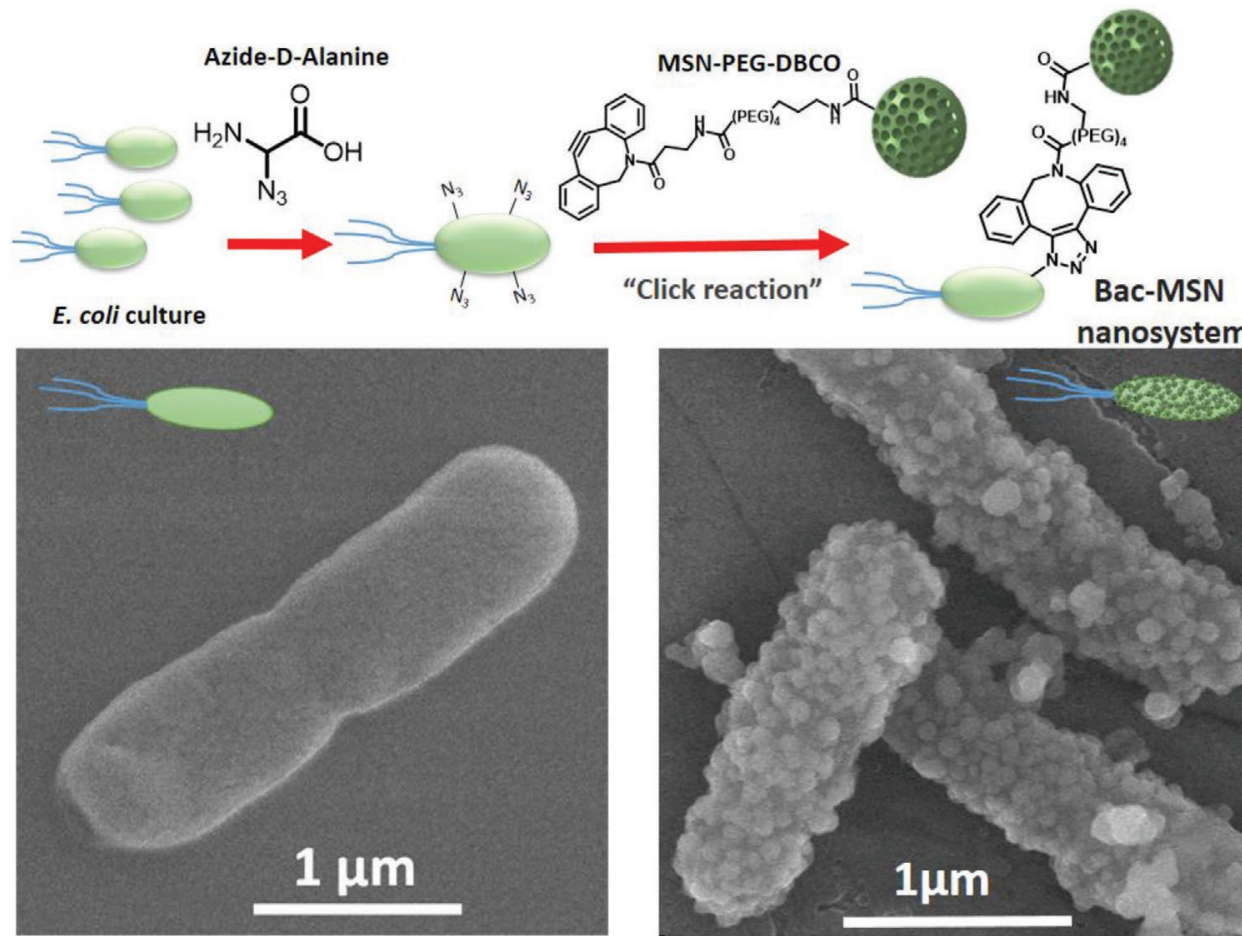

Figure 2. Upper image shows a schematic procedure of "click reaction" between Bacteria- $\mathrm{N}_{3}$ and MSN-PEG-DBCO nanoparticles. Lower images show SEM micrographs of nude bacteria (left) and bacteria with MSN attached on their surface (right).

\subsection{Evaluation of Mobility and Penetration Capacity of Bac-MSN in 3D Nutrient-Rich Collagen Gels}

\subsubsection{Mobility of Bac-MSN toward Gradient Assay}

The capacity of bacteria to transport nanosystems to different locations has been previously demonstrated, showing that an

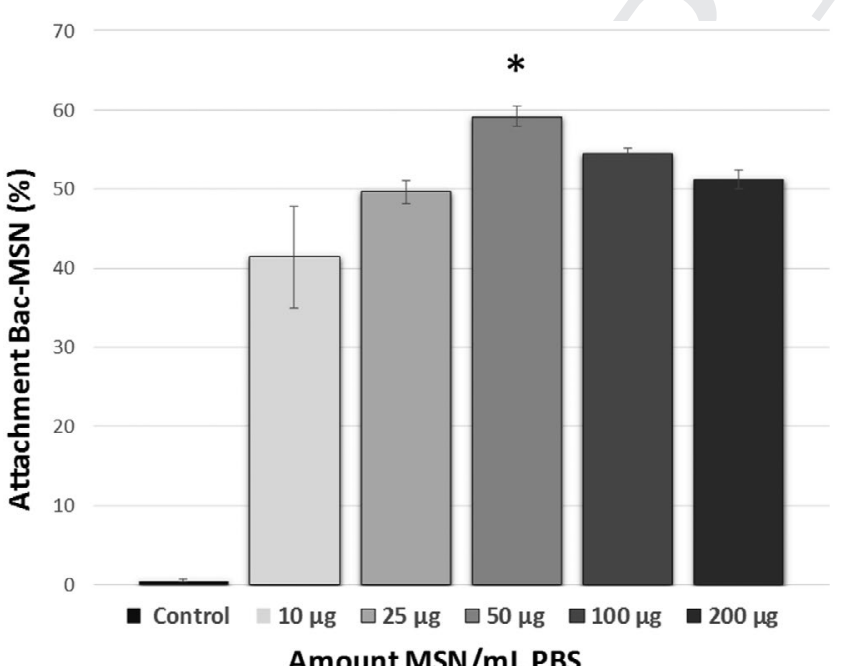

Figure 3. Flow cytometry corresponding to percentage of bacteria which incorporate MSN-PEG-DBCO on their surface depending on the nanoparticle concentration. Bars represent mean \pm standard error of the mean $(n=3) . * p<0.05$ versus 10 and $25 \mu \mathrm{g}$ of MSN. (Student's two-tailed $t$-test). anchored nanosystem not affect significantly to the mobility capacity of E. coli comparing with free bacteria. ${ }^{[40]}$ Mobility and penetration capacity of bacteria with MSN attached on their surface (Bac-MSN) was evaluated employing 3D collagen matrices enriched in nutrients that act as bacteria chemoattractors. In this case, the collagen matrix was impregnated with a nutrient media composed by complemented Dulbecco's modified Eagle's medium (DMEM) with $10 \%$ of fetal bovine serum (FBS) and L-glutamine prepared without antibiotic to preserve the bacteria alive. These gels were placed at a corner of 12 -well plates and PBS was added as medium for bacteria migration. Simultaneously, in the opposite corner, $100 \mu \mathrm{L}$ of a suspension of Bac-MSN was added and incubated at room temperature (RT) in static conditions during $3 \mathrm{~h}$ (Figure 4). Thus, thanks to the capacity of bacteria to navigate toward favorable locations, the migration of bacteria to the $3 \mathrm{D}$ collagen gel transporting with them the nanoparticles attached were monitored employing fluorescence microscopy, observing fluorescence due to nanoparticles which were present in the collagen gel after the incubation time. Previous to the microscopy observation, gels were washed three times with antibiotic-containing PBS $\left(0.1 \mathrm{mg} \mathrm{mL}^{-1}\right.$ of Levofloxacin) to kill the bacteria and gels were incubated with paraformaldehyde $(3 \% \mathrm{w} / \mathrm{v})$ overnight to freeze the position of the nanoparticles in the gel. The results indicate that when the nanoparticles were transported on bacteria surface, they were present on and inside the gel in higher amount than in the case of free nanoparticles. Figure 4 shows a time comparison of the migration process of Bac-MSN. At the beginning of the experiment (time $=0 \mathrm{~h}$, Figure 4A), gels are completely free of nanoparticles while after $3 \mathrm{~h}$, the high presence of nanoparticles 

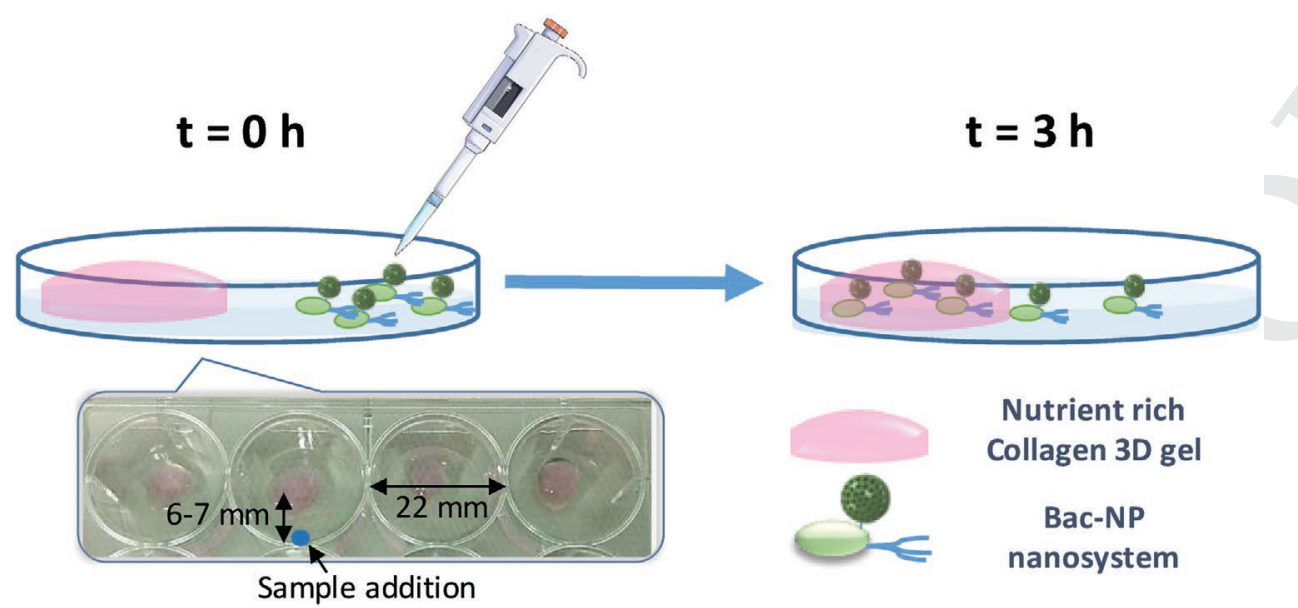

Nutrient rich

Collagen 3D gel

Bac-NP nanosystem
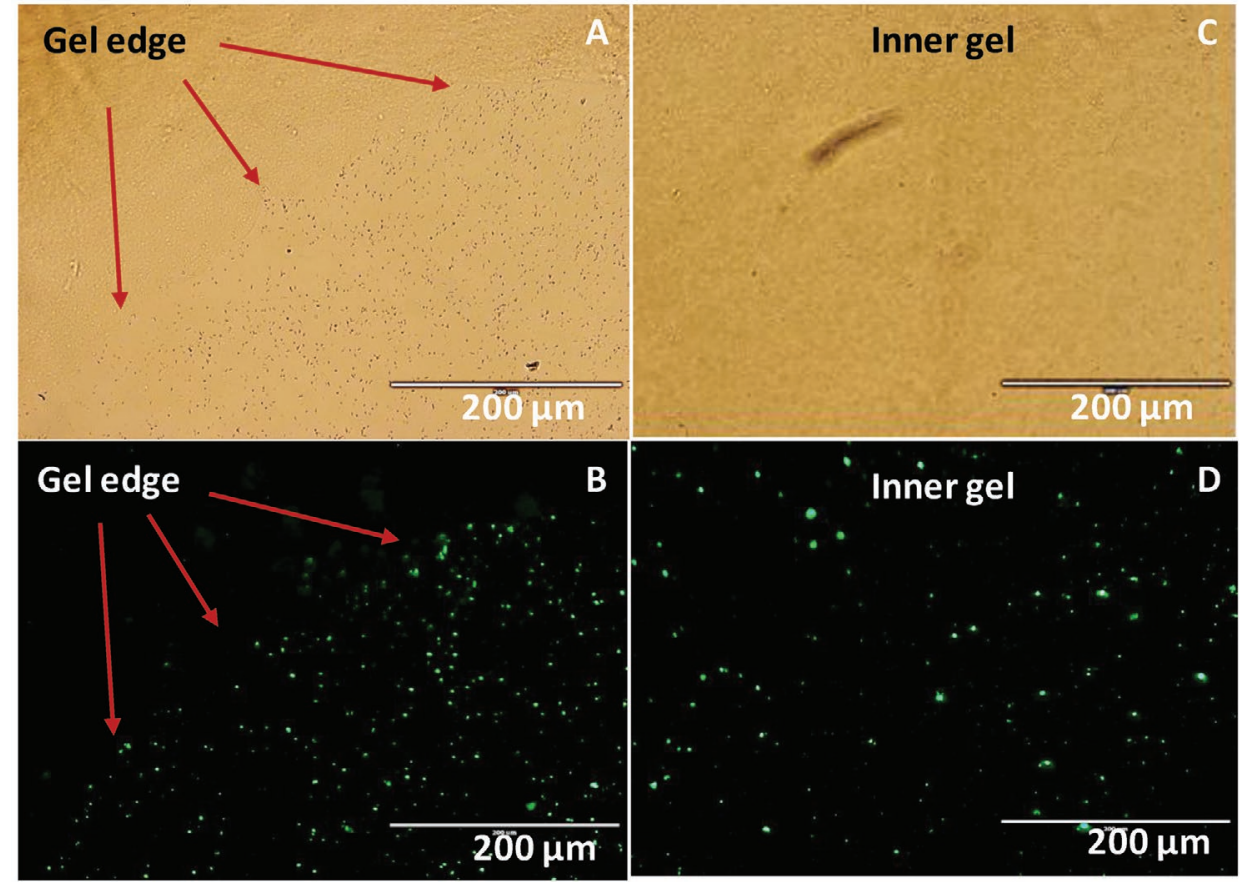

Figure 4. Top: Motility assay scheme of Bac-MSN in a nutrient-rich collagen 3D gel. Bottom: Microscopy images of a gel edge (left images) with Bac- 41 MSN added at $t=0 \mathrm{~h}$ in transmittance $\mathrm{A}$ ) and fluorescence microscopy $\mathrm{B}$ ), in which nanoparticles correspond to green dots. Right images show the 42 central area of the same gel at $t=3 \mathrm{~h}$ in transmittance $\mathrm{C}$ ) and fluorescence microscopy $\mathrm{D}$ ) images.

in the whole inner gel in form of green dots was evidently visible by fluorescence microscopy (Figure 4D).

\subsubsection{Penetration of Bac-MSN in 3D Gel Assay}

One of the most important properties which can be achieved by self-propelled nanocarriers is their high penetration in tumoral tissues. Bacteria can transport nanoparticles to specific zones as tumoral tissues due to their ability to detect chemical gradients and additionally, they can penetrate deeply into the diseased tissue. This last property is of paramount importance because to achieve a homogeneous nanocarrier distribution in the target tissue is a compulsory requirement for improving the efficacy of nanomedicines. In order to evaluate the penetration of Bac-MSN in a tumoral matrix-mimic model, a 3D collagen 45 gel with tumoral cells embedded within a nutrient-rich organic 46 matrix has been employed. In this case, we have incorporated 47 into the collagen gel HT1080 human fibrosarcome cells because 48 the rheological properties of the resulting gel which contains 49 tumoral cells embedded are close to real tumoral matrix, as has 50 been reported elsewhere. ${ }^{[41]}$ Thus, due to the nutrient guiding 51 capacity of bacteria, the nanoparticles carried by these organ- 52 isms could reach inner zones of the 3D matrix. It is important 53 to remark that this is a simple model that has been applied only 54 to test the bacteria capacity to transport nanoparticles without 55 losing their motility.

Bac-MSN were placed at the top of collagen gels and 57 gels were incubated during $3 \mathrm{~h}$. Free MSN-PEG-DBCO was 58 employed as a control. After this time, gels were thoroughly 59 
A
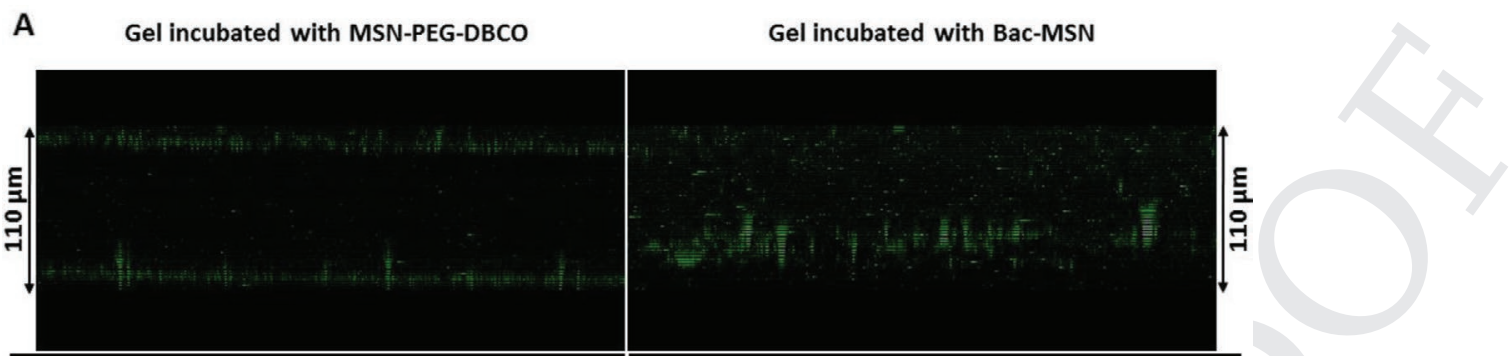

B

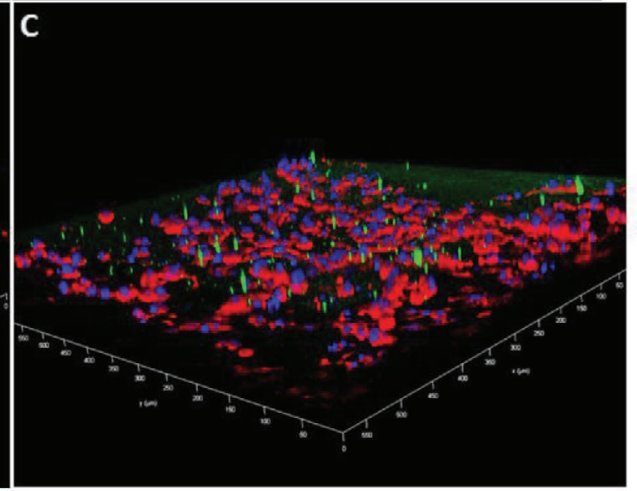

Figure 5. A) Confocal microscopy Z-axis projection of MSN-PEG-DBCO and Bac-MSN placed on 3D collagen gel. B,C) Confocal microscopy 3D panoramic view of collagen gels which contains HT1080 human fibrosarcoma cells embedded incubated with MSN-PEG-DBCO B) and Bac-MSN C), respectively. Green dots correspond to FITC-labeled MSN, red color corresponds to actin filaments and blue color correspond to cell nuclei.

washed to remove the particles which did not penetrate the collagen matrix and the particles were visualized employing confocal microscopy. Free particles were accumulated on the gel edges being not capable to penetrate the collagen matrix. Particles attached on the bacteria surface were localized in the whole tissue, which indicate that bacteria were able to penetrate the collagen matrix colonizing the gel, as can be observed in Figure 5A. In order to visualize more properly the location of the particles and the distribution of tumoral cells in the matrix model, HT1080 cells were stained with Phalloidin-Atto 565 that label in red the actin filaments and the cell nuclei were stained with DAPI (blue). Similar to the previous assay, the green dots which correspond to the fluorescein labeled nanoparticles were distributed in the whole tissue only in the case of Bac-MSN (Figure $5 \mathrm{C}$ ), while they remain on the periphery of the gel in the case of free particles (Figure 5B).

\subsection{Evaluation of Antitumoral Properties of Bac-MSN@Dox in 3D Collagen Tumoral Matrix Model}

\subsubsection{Doxorubicin Loading into MSN (MSN@Dox) and Bacterial Inhibition Assay}

Once the mobility and penetration capacity of Bac-MSN were validated, their capacity to transport antitumoral agents to the tumoral space was tested loading the MSN with a potent cytotoxic drug, Dox, which is widely used in oncology. Its hydrophobicity becomes an ideal drug for the loading into MSN, due to the release from the porous at physiological conditions is slow. ${ }^{[42]}$ However, at mild acidic environment, as is usually present in most of the solid tumors, ${ }^{[43]}$ Dox release from the MSN is around 2.5-fold times, so it has a pH-responsive behavior by itself. Thus, MSN were loaded with Dox by immersion in a highly concentrated Dox solution in PBS $\left(6 \mathrm{mg} \mathrm{mL}^{-1}\right)$, yielding nanoparticles loaded with Dox. The release profiles of Dox were obtained at different $\mathrm{pH}$ (7.2 and 5.5, respectively), as are shown in Figure S13A of the Supporting Information, confirming the $\mathrm{pH}$-responsive behavior of these Dox-loaded nanoparticles.

Additionally, the influence of the released Dox in bacteria growth and viability was evaluated exposing them to the Dox released from MSN at $50 \mu \mathrm{g} \mathrm{mL} \mathrm{m}^{-1}$ of concentration during the time of the anchoring experiment $(4 \mathrm{~h})$. For it, we performed a dilution series (from $10^{-5}$ to $10^{-7}$ ) and we pipetted five replicas of $10 \mu \mathrm{L}$ onto agar plates for each dilution, and then we counted the number of colony forming units (CFU) for the $10^{-5}$ dilution, where the number of colonies were statistically representative (between 30 and $300 \mathrm{CFU}$ ). Data shown a minor decrease in the bacterial viability of $20.5 \%$ (see Figure S13B, Supporting Information). These results agree with other data reported by other research groups which indicate that the presence of Doxorubicin does not affect significantly neither growth nor viability of bacteria. ${ }^{[25]}$

\subsubsection{Evaluation of Antitumoral Potential of Bac-MSN@Dox}

The capacity of bacteria to transport Dox-loaded MSN (BacMSN@Dox) was tested employing a homemade tumoral matrix model composed by a Transwell in which a collagen shell of 200-300 $\mu \mathrm{m}$ was grown on the top Transwell insert membrane, while HT1080 cells were seeded at the bottom (see Figure 6). The role of this collagen shell is to act as a barrier which

\section{1}



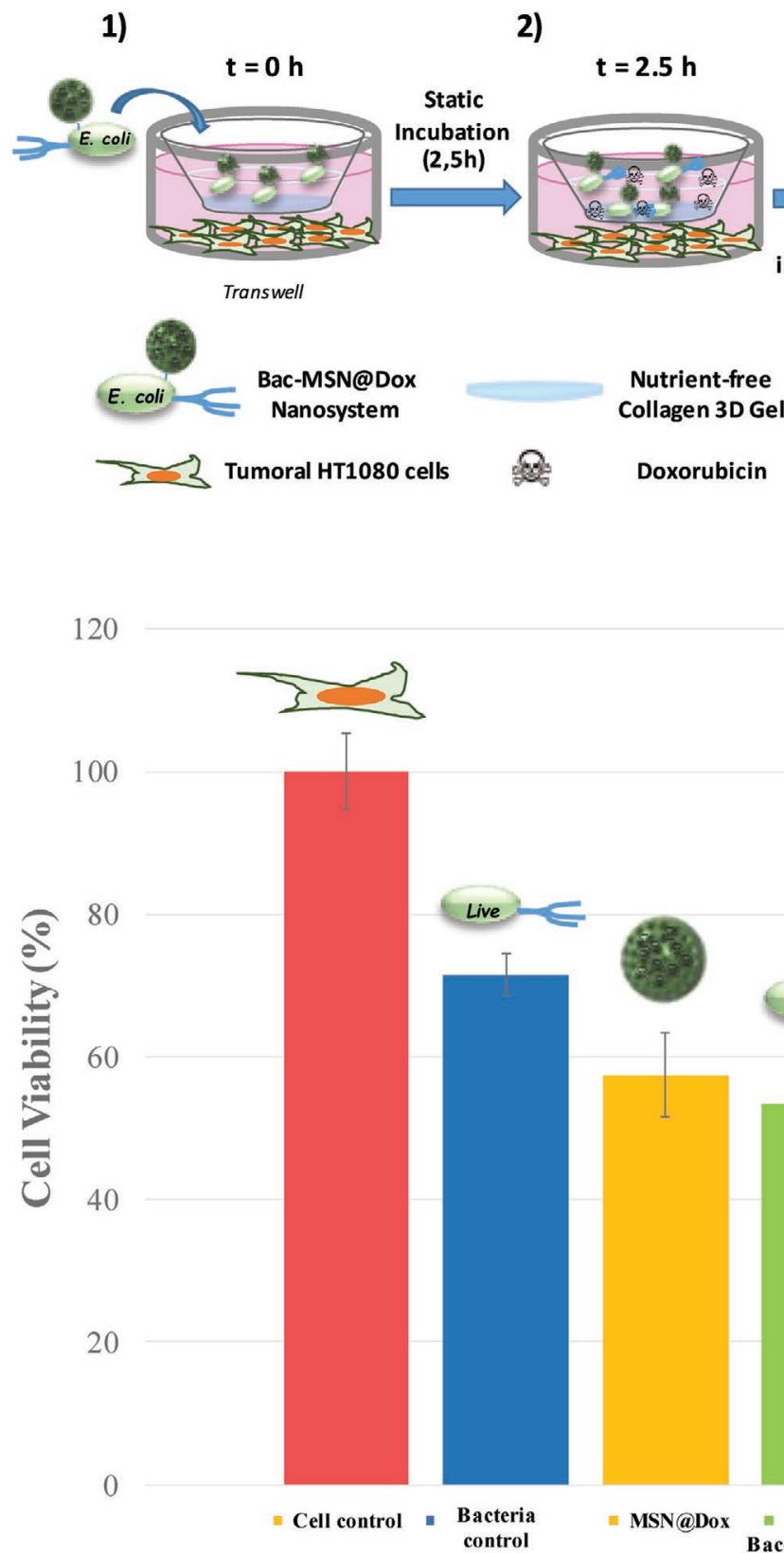

Nutrient-free Collagen 3D Gel

Doxorubicin

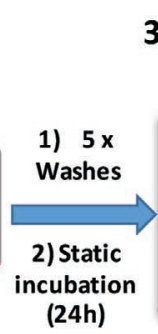

3)

\section{$t=24 h$}
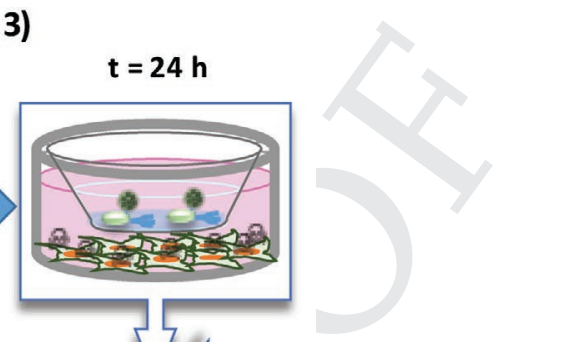

2

Figure 6. Upper image shows the schematic procedure for cytotoxicity experiment: 1) Transwell with HT1080 human fibrosarcoma cells seeded in the 44 lower compartment, and 3D collagen gel covering the upper compartment of the insert. Sample is added in the surface of this gel. 2) After $2.5 \mathrm{~h}$ static 45 incubation, bacteria had penetrated and are retained inside the gel. The lower and upper part of the Transwell were abundantly washed and incubated with fresh culture medium. 3) $24 \mathrm{~h}$ after incubation, bacteria retained inside the gel have liberated the Doxorubicin loaded into the MSN and it has diffused to the culture medium. Cell viability was measured at this point. Lower graphic show cytotoxicity results for each control and sample. Bars represent mean \pm standard error of the mean $(n=3)$. * $p<0.05$ versus Dead Bac-MSN@Dox; MSN@Dox, and Cell control (Student's two-tailed $t$-test).

hamper the nanoparticles to reach inner zones. Bac-MSN@Dox (Live) was placed on the top of the collagen gel immersed in PBS and after an incubation time of $2.5 \mathrm{~h}$, the collagen surface was thoroughly washed with PBS to remove the particles which were not able to penetrate into the collagen shell, and the cell culture media at the bottom of the Transwell was replaced and repeatedly washed to eliminate the Dox prematurely released during this time. The cells were incubated for $24 \mathrm{~h}$ to let time for Dox release and in the presence of antibiotic in order to kill the bacteria which can interfere in the cell viability evaluation. 51 In this assay, the bacteria role is only to introduce deeply the 52 nanoparticles into the gel. Free nanoparticles are not capable 53 to penetrate into the collagen gel, as was tested in the previous 54 experiments, and therefore, they were rapidly removed from the 55 collagen surface. Cell viability was determined by Alamar blue 56 assay. Different controls were carried out in parallel placing 57 at the top of collagen gel: bacteria alone, MSN@Dox, and 58 Bac-MSN@Dox (Dead) (incubated in PBS with Levofloxacin), 59 
and were treated following the same protocol in order to evaluate the influence of each system. Graphic of Figure 6 shows that the addition of bacteria alone provokes a slight decrease in cell viability, which was around 70\%. MSN@Dox induced a more pronounced effect due to Dox released by the particles, which remained adsorbed on the collagen surface after the washing steps. This effect is almost the same as that achieved by the MSN@Dox attached on dead bacteria, due to their obvious lack of motility (57\% and 53\% of cell viability, respectively). Finally, Bac-MSN@Dox exhibited the best performance, yielding a significant tumoral cell mortality being able to destroy almost $80 \%$ of the tumoral cells. The presence of fully functional bacteria allows the penetration of the nanocarriers deeply into the collagen matrix resisting the washing steps. The continuous Dox release from the mesoporous silica matrix fixed there induce an efficient antitumoral effect over time.

\subsection{Evaluation of Immunogenic Response Against the Nanosystem Bac-MSN}

For future biomedical assays, it is very important to evaluate the immune response caused by our nanosystem. In addition to producing toxicity due to the release of Doxorubicin, we could provoke an activation of the immune system that could be a new weapon to achieve better clinical outcomes against the tumor. To elucidate whether our nanodevice (Bac-MSN) induces any immune system response, we detected intracellular Interferon gamma (IFN- $\gamma$ ) production by different immune cells. Mononuclear cells isolated from peripheral blood of a healthy donor were cocultured with our nanodevice at scaling doses. After more than $5 \mathrm{~h}$ in presence of Golgi apparatus inhibitor (Monensin), IFN- $\gamma$ were detected within immune cells by flow cytometry. Serial gating of the different circulating populations (Figure S14, Supporting Information,) showed an $\approx 100$-fold accumulation of IFN- $\gamma$ in monocytes in response to the highest dose of our nanodevice and $\approx 20$-fold with nanoparticles alone (Figure 7-left). Both T-cells and B-cells showed $\approx 20$ and $\approx 7$-fold less of intracellular IFN- $\gamma$, suggesting that monocytes are more sensitive, while not significance accumulation was observed in presence of nanoparticles (MSN-PEG-DBCO) alone (Figure 7 center and right). On the other hand, light responses are presented in all 1 populations in presence of high dose of bacterium. Altogether, 2 we observed that our biohybrid nanodevice Bac-MSN (NP-BAC 3 in graphs) produce IFN- $\gamma$ in a synergic manner in all immune cells, particularly strong retention in monocytes.

\section{Conclusions}

In conclusion, a novel strategy to enhance the penetration of drug loaded mesoporous silica nanoparticles in 3D collagen tumoral matrix models through their covalent attachment on the surface of living bacteria have been presented. Bacteria present a remarkable tumor-homing capacity guided by the specific conditions present there, such as the necrotic and hypoxic environment. These tiny organisms have been widely studied for cancer treatment due to their potential capacity to reach even the hardly accessible core of solid tumors. ${ }^{[26]}$

In this work, bacteria wall was decorated with azide groups to allow the covalent anchorage of mesoporous silica nanoparticles functionalized with strained cycloalkynes click-type reactions. The high chemoselectivity of the azide-alkyne cycloaddition allowed the easy incorporation of nanoparticles loaded with cytotoxic drugs in mild conditions on the surface of living bacteria. The capacity to transport the nanoparticles to deep zones of tumoral matrix was evaluated employing 3D tumor models composed by a dense collagen matrix which contains human fibrosarcoma cells embedded into the organic matrix. The results indicated that nanoparticles carried by bacteria were homogeneously found in the whole tissue, even in deep zones, whereas free nanocarriers were concentrated only in the periphery. This fact allowed an improved release of cytotoxic drugs which caused a significantly higher tumoral cell mortality in comparison with free nanoparticles ( $80 \%$ vs $40 \%$, respectively).

The immune responses obtained in the immunogenic analysis indicate how our nanosystem is able to activate innate and acquire immune cells suggesting a future use for reactivating the intratumoral immune cells which are silenced by tumor microenvironment. Moreover, the capacity of bacteria to transport nanoparticles within dense collagen matrices would be a valuable strategy for improving the efficacy of
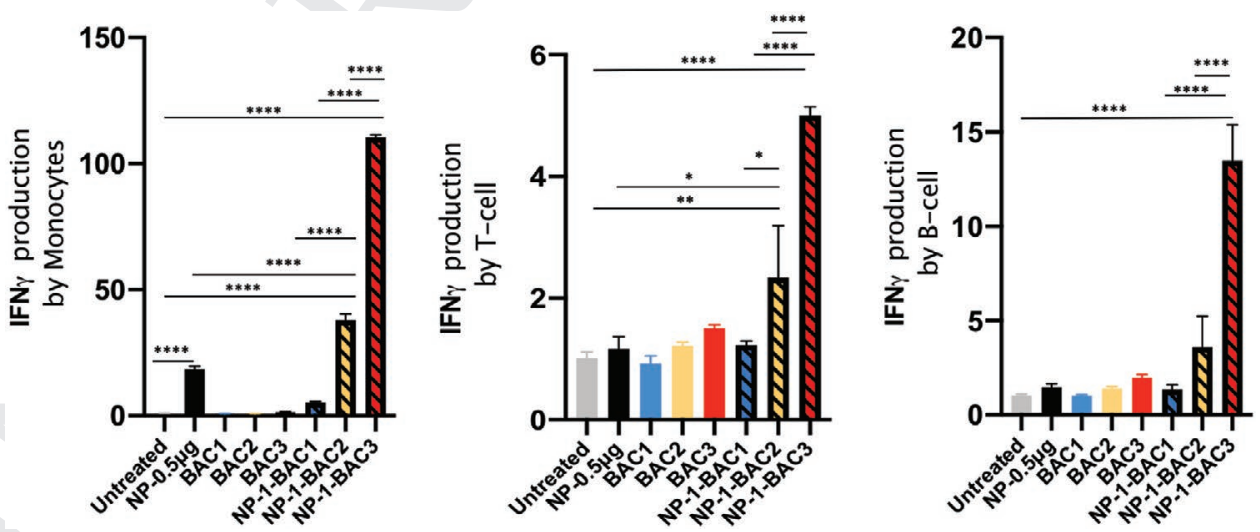

Figure 7. Graphs represent the percentage of IFN- $\gamma$ measured in monocytes (left), T lymphocytes (middle), and B lymphocytes (right) by flow cytometry. BAC1: $1.91 \times 10^{5}$ cells mL ${ }^{-1}$; BAC2: $1.91 \times 10^{6}$ cells mL ${ }^{-1}$; BAC3: $1.91 \times 10^{7}$ cells mL ${ }^{-1}$. NP-0.5 $\mu \mathrm{g}: 0.5 \mu \mathrm{g}$. NP-BAC1: $0.05 \mu \mathrm{g}-1.91 \times 10^{5} \mathrm{cells} \mathrm{mL}^{-1}$. NP-BAC2: $0.5 \mu \mathrm{g}-1.91 \times 10^{6}$ cells $\mathrm{mL}^{-1}$. NP-BAC3: $5 \mu \mathrm{g}-1.91 \times 10^{7}$ cells $\mathrm{mL}^{-1} . * p<0.05$, $* * p<0.01$, ***** $* 0.0001$. 
nanomedicines in the fight against this disease. For a future application in in vivo models, several ways to control the bacterial pathogenicity should be considered, as the employ of attenuated or genetically modified bacteria, the employ of antibiotics after treatment, or the adjust or the bacteria dose.

\section{Experimental Section}

Materials and Strains: Hexadecyltrimethylammonium bromide (CTAB), Tetraethyl orthosilicate (TEOS), and dry Toluene were purchased from Sigma-Aldrich. Ammonium hydroxide $\left(\mathrm{NH}_{4} \mathrm{OH}, 28-30 \%\right)$ from Fluka; (3-aminopropyl)triethoxysilane (APTES), TESPSA, and Fluorescein isothiocyanate, isomer I (FITC) were purchased from Abcr; Absolute Ethanol from Panreac; DBCO-PEG- $\mathrm{NH}_{2}$, and (R)-2-Amino-3azidopropanoic acid hydrochloride (azide- $D$-alanine) were purchased from Jena Bioscience Gmbh. N,N'-Diisopropylcarbodiimide (DIC), $\mathrm{N}$-Hydroxysuccinimide (NHS), TAMRA-Azide, Ammonium nitrate $\left(\mathrm{NH}_{4} \mathrm{NO}_{3}\right)$, and Dibenzocyclooctyne-PEG - Fluor 545 (TAMRA-DBCO) from Sigma-Aldrich.

DMEM, Luria-Bertani (LB) medium, Trypsin, FBS, and AntibioticAntimycotic (Anti-Anti) 100x from GIBCO. Rat tail Collagen (type I) Life Technologies S.A.; 10X PBS Buffer solution $\mathrm{pH}=7.4$ from Ambion. Sodium hydroxide $(\mathrm{NaOH})$, Dimethyl sulfoxide (DMSO), Paraformaldehyde, Phalloidin-Atto 565, 4',6-diamidino-2-phenylindole (DAPI), and Doxorubicin hydrochloride (Dox) from Sigma-Aldrich; Alamar blue solution from Invitrogen. E. coli strain Seattle 1946 (ATCC 25 922) was used as a model of Gram negative bacteria. HT1080 human fibrosarcome cell line was obtained from ATCC (ATCC CCL-121).

Synthesis of Mesoporous Silica Nanoparticles: To prepare green fluorescent dye-labeled MSN, 1.5 $\mu \mathrm{L}$ of APTES was added to a solution of $1.5 \mathrm{mg}$ of FITC dissolved in $1 \mathrm{~mL}$ of absolute ethanol and was kept under magnetic stirring during $1 \mathrm{~h}$ at RT in the dark. Separately, $0.290 \mathrm{~g}$ of $C T A B$ was dissolved $150 \mathrm{~g}$ in a solution of ammonium hydroxide $\left(\mathrm{NH}_{4} \mathrm{OH}\right) 0.22 \mathrm{M}$ and was incubated at $50^{\circ} \mathrm{C}$ under magnetic stirring for $1 \mathrm{~h}$ in a $250 \mathrm{~mL}$ beaker sealed with parafilm. Then, both $3 \mathrm{~mL}$ of $0.88 \mathrm{M}$ TEOS in ethanol and FITC-APTES solution were added to the surfactant solution after adjusting the stirring speed to 600 revolutions per minute (rpm). The mixture was incubated at $50{ }^{\circ} \mathrm{C}$ under magnetic stirring for $1 \mathrm{~h}$ without parafilm, then the solution was aged at $50{ }^{\circ} \mathrm{C}$ overnight under static conditions. Subsequently, the nanoparticles were subjected to a hydrothermal treatment at $70{ }^{\circ} \mathrm{C}$ for $20 \mathrm{~h}$ before being collected by centrifugation and washed three times with water and ethanol, respectively. The ion exchange method was employed for the removal of the surfactant by placing the particles in $500 \mathrm{~mL}$ of a solution of $95 \%$ ethanol, $5 \%$ water, and $10 \mathrm{~g}$ of $\mathrm{NH}_{4} \mathrm{NO}_{3}$ per liter at $80^{\circ} \mathrm{C}$ overnight. The MSNs were washed three times with ethanol and were finally stored in pure ethanol.

Functionalization of the MSNs with DBCO-PEG-NH $\mathrm{H}_{2}$ (MSN-PEG$D B(O)$ : The nanoparticles surface was functionalized in consecutive steps. First, MSNs were functionalized with TESPSA providing functional carboxylic groups (MSN-COOH), which allow the subsequent binding of DBCO-PEG- $\mathrm{NH}_{2}$ trough carbodiimide-mediated coupling to yield MSN-PEG-DBCO. For the obtention of MSN-COOH, $120 \mathrm{mg}$ of dried MSNs were dissolved in $10 \mathrm{~mL}$ of anhydrous toluene $(99.8 \%)$ under $\mathrm{N}_{2}$ atmosphere and gently scattered in an ultrasound bath. After vigorous stirring during $30 \mathrm{~min}$ at $80{ }^{\circ} \mathrm{C}, 18 \mathrm{mg}$ of TESPSA dissolved in $5 \mathrm{~mL}$ of anhydrous toluene was added to the mixture. The resulting mixture was stirred overnight at $110^{\circ} \mathrm{C}$ under $\mathrm{N}_{2}$. Then, the sample was collected by centrifugation at $13000 \mathrm{rpm}$ for $1 \mathrm{~h}$ and washed three times with toluene and ethanol and dried under vacuum. After that, $15 \mathrm{mg}$ of MSN-COOH was suspended in N,N-dimethylformamide (DMF) and $0.035 \mathrm{mmol}$ of DIC and $0.038 \mathrm{mmol}$ of NHS were added. This mixture was stirred for 30 min under $\mathrm{N}_{2}$ atmosphere at RT. Then, $0.015 \mathrm{mmol}$ of DBCO-PEG- $\mathrm{NH}_{2}$ was added and stirred overnight at RT. The obtained nanoparticles were washed with $\mathrm{DMF}, \mathrm{H}_{2} \mathrm{O}$, and absolute ethanol, respectively, and were finally stored in absolute ethanol. The resulting samples were named as MSN-PEG-DBCO.
The resulting materials were deeply characterized through different 1 techniques as: DLS to determinate the size distribution and electrophoretic 2 mobility measurements to calculate the values of zeta-potential 3 (Zetasizer Nano ZS equipped with a $633 \mathrm{~nm}$ "red" laser); attenuated total reflectance (ATR)-FTIR Thermo Nicolet nexus equipped with a 4 Goldengate attenuated total reflectance device) for the identification of 5 functional organic groups; thermogravimetric and differential thermal 6 analysis (Perkin Elmer Pyris Diamond TG/DTA analyzer, with $5^{\circ} \mathrm{C} \mathrm{min}^{-1} 7$ heating ramps, from $\mathrm{R}$ to $600^{\circ} \mathrm{C}$ ) for the quantification of the loss of 8 organic mass of each sample; and TEM (JEOL JEM 2100 instrument 9 operated at $200 \mathrm{kV}$, equipped with a CCD Camera (KeenView Camera) to 10 observe the morphology and size of nanoparticles.

Anchoring of MSN-PEG-DBCO to the E. Coli Surface (Bac-MSN): E. coli strain was routinely grown at $37^{\circ} \mathrm{C}$ overnight after inoculation of $20 \mu \mathrm{L}$ of $E$. coli into $10 \mathrm{~mL}$ of LB medium. This overnight culture was diluted 13 1:5 with LB medium until obtaining a suspension with optical density 14 $\left(\mathrm{OD}_{600}\right)$ of $0.25\left(2 \times 10^{8}\right.$ cells $\left.\mathrm{mL}^{-1}\right)$. Then, $10 \mu \mathrm{L}$ of a $10 \times 10^{-3} \mathrm{M}$ of azide$D$-alanine solution in DMSO were added to the $E$. coli suspension and incubated at $37{ }^{\circ} \mathrm{C}$ with slight orbital stirring for $1 \mathrm{~h}$. After that, it was centrifuged two times at $8000 \mathrm{rpm}$ for $5 \mathrm{~min}$ and suspended with PBS. Afterward, the resulting bacteria suspension was incubated with $50 \mu \mathrm{L}$ of well-dispersed MSN-PEG-DBCO $\left(1 \mathrm{mg} \mathrm{mL}^{-1}\right)$ suspension in PBS at $37^{\circ} \mathrm{C}$ with slight orbital stirring for $1.5 \mathrm{~h}$. Finally, it was centrifuged two times at $8000 \mathrm{rpm}$ for $5 \mathrm{~min}$ and suspended with PBS to obtain the Bac-MSN with an ending $\mathrm{OD}_{600}$ of $0.291\left(2.33 \times 10^{8}\right.$ cells $\left.\mathrm{mL}^{-1}\right)$.

For the evaluation of the binding efficiency of MSN to Bacteria by fluorescence-activated cell sorter (FACS, Bac-MSN was suspended in a $3 \%$ paraformaldehyde solution during $1 \mathrm{~h}$ at RT to avoid the growth of bacteria. Then, for the detection of bacteria in the cytometry equipment (FACSCalibur, Becton Dickinson), they were stained with $\mathrm{PI}$ as red fluorescence labeling.

This anchoring was also examined by SEM. To observe it, Bac-MSN were suspended with a $3 \%$ paraformaldehyde solution for $1.5 \mathrm{~h}$. Then, it was dehydrated in increasing series of water-ethanol solutions $(10-100 \%)$, and finally air-dried in vacuum. The samples were sputter coated with a layer of gold and examined in a JEOL JSM 7600F.

Preparation of 3D Collagen Gels Enriched with Nutrients: Briefly, $2 \mathrm{~mL}$ of Rat Tail Collagen type I $\left(3 \mathrm{mg} \mathrm{mL}^{-1}\right)$ and $0.6 \mathrm{~mL}$ of complemented DMEM (DMEM medium with $10 \% \mathrm{FBS}$ and L-Glutamine) were mixed at $0{ }^{\circ} \mathrm{C}$ and subsequently $100 \mu \mathrm{L}$ of a $2 \mathrm{M} \mathrm{NaOH}$ solution was added until neutral $\mathrm{pH}$. Then, $0.5 \mathrm{~mL}$ of FBS and $1 \mathrm{~mL}$ of complemented DMEM were added to the solution at $0{ }^{\circ} \mathrm{C}$. Afterward, $0.5 \mathrm{~mL}$ of this mixture was added to the wells of a 24 -well plate and incubated at $37{ }^{\circ} \mathrm{C}$ at an atmosphere of $5 \%$ $\mathrm{CO}_{2}$ for $1 \mathrm{~h}$ to promote the collagen gelification. To avoid gel cracking, the edge of each well was encircled with a needle. Finally, $250 \mu \mathrm{L}$ of complemented DMEM medium was added, and incubated at $37{ }^{\circ} \mathrm{C}$ at an atmosphere of $5 \% \mathrm{CO}_{2}$ overnight. The resulting collagen gels were employed for the further experiments 1 day after gels formation.

For the collagen gel containing HT1080 human fibrosarcoma cells, the cells were embedded into the collagen matrix following the same procedure by adding $1 \mathrm{~mL}$ of complemented DMEM with a suspension of cells $\left(5 \times 10^{5}\right.$ cells $\left.\mathrm{mL}^{-1}\right)$ instead of complemented DMEM alone. As well as above gels, they were used 4 days after for the confocal microscopy (Leica SP2) analysis with the aim of evaluating the bacteria penetration experiment.

In Vitro Bacteria Penetration and Mobility Assay: The previously prepared 3D collagen gels enriched with nutrients were transferred to the corner of a well of a 12-well plate and $0.4 \mathrm{~mL}$ of $1 X$ PBS was added to cover it. Straightaway, $100 \mu \mathrm{L}$ of freshly prepared Bac-MSN sample was added in the other corner of the well $(\approx 6-7 \mathrm{~mm})$, and incubated at RT for $3 \mathrm{~h}$ without agitation. Then, the supernatant was removed and gel was washed three times with PBS. This experiment was monitored by EVOS fluorescence microscopy. The same procedure was employed for the gel penetration experiment, but instead of adding the nanosystem on one side of the transwell (mobility assay), it was added over the top of the gel. Then, gels were incubated in a $3 \% \mathrm{w} / \mathrm{v}$ paraformaldehyde solution overnight. Next day, cell-containing collagen gels were stained with $10 \mu \mathrm{L}$ of Phalloidin-Atto $565\left(10 \mu \mathrm{g} \mathrm{mL}^{-1}\right.$ solution $)$ and $1 \mu \mathrm{L}$ DAPI 15 26 " 34 41 43 45 46 .

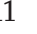
17

\section{8} 19 20 21 ${ }^{25}$  33 35 36 37 38 39 40 42 43 44 50 51 52 s. (5) 58

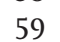


(1 $\mu \mathrm{g} \mathrm{mL}^{-1}$ solution) and washed two times with PBS. Thereafter, gels were analyzed by confocal microscopy at different depths.

MSN-PEG-DBCO Loading with Doxorubicin (MSN@Dox) and Effect on Bacterial Viability: $2.5 \mathrm{~mL}$ of a solution of Dox in PBS $\left(6 \mathrm{mg} \mathrm{mL}^{-1}\right)$ was added to a well-dispersed suspension of MSN-PEG-DBCO in $2 \mathrm{~mL}$ of PBS $\left(5 \mathrm{mg} \mathrm{mL}^{-1}\right)$ and were stirred in an orbital shaker overnight at RT. Then, Dox-loaded MSN-PEG-DBCO (MSN@Dox) were centrifuged at $13000 \mathrm{rpm}$ for $10 \mathrm{~min}$ and washed $5 \times$ PBS. Final centrifugation pellet was stored at $4{ }^{\circ} \mathrm{C}$. Loading capacity of nanoparticles was confirmed by Infrared spectroscopy (FTIR) and quantitatively evaluated by TCA and measuring the fluorescence of Dox $\left(\lambda_{\mathrm{exc}}=480 \mathrm{~nm} ; \lambda_{\mathrm{em}}=600 \mathrm{~nm}\right)$ liberated along the time (Figures S1C and S13A, Supporting Information).

To evaluate the effect of MSN@Dox on bacterial viability, E. coli strain was routinely grown at $37{ }^{\circ} \mathrm{C}$ overnight after inoculation of $10 \mu \mathrm{L}$ of $E$. coli into $5 \mathrm{~mL}$ of LB medium. This overnight culture was diluted with LB medium until obtaining a suspension with a $\mathrm{OD}_{600}$ of $\approx 0.25$. Then, $50 \mu \mathrm{L}$ of a MSN@Dox suspension $\left(1 \mathrm{mg} \mathrm{mL}^{-1}\right)$ in PBS were added to the $E$. coli suspension and incubated at $37{ }^{\circ} \mathrm{C}$ with orbital stirring for $4 \mathrm{~h}$ (same conditions as in the procedure of anchoring nanoparticles to bacteria). After that, a dilution series of the mixture (from $10^{-5}$ to $10^{-7}$ ) was performed and $10 \mu \mathrm{L}$ of each dilution onto agar plates was pipetted and, thereafter it was incubated at $37^{\circ} \mathrm{C}$ overnight. Next day, the number of CFU was determined (Figure S13B, Supporting Information).

Preparation of 3D Collagen Covered Transwell as Tumoral Matrix Model: For this study, the collagen gels were prepared without nutrients in the same way that has been described before, but instead of adding DMEM medium, it was replaced by PBS on each step. Then, $0.2 \mathrm{~mL}$ of this mixture was added to each Transwell insert of a 12-well plate and was incubated at $37{ }^{\circ} \mathrm{C}$ at an atmosphere of $5 \% \mathrm{CO}_{2}$ overnight to promote the gelification, obtaining a gel thickness of $200 \mu \mathrm{m}$. At the same time, $20000 \mathrm{HT} 1080$ human fibrosarcoma cells $\mathrm{cm}^{-2}$ were seeded at the bottom of each well of a 12-well plate with complemented DMEM medium at $37^{\circ} \mathrm{C}$ in an atmosphere of $5 \% \mathrm{CO}_{2}$.

In Vitro Cytotoxicity Assay in Tumoral Matrix Model: After $24 \mathrm{~h}$, wells of 12-well plate seeded with cells were washed three times with PBS and $1.5 \mathrm{~mL}$ of complemented DMEM without Anti-Anti was added. Previously prepared gel-containing transwells were transferred to this 12-well plate with cells, and $100 \mu \mathrm{L}$ of the corresponding sample suspension (Live Bac-MSN@Dox, Dead Bac-MSN@Dox, MSN@Dox [1 mg mL $\mathrm{m}^{-1}$, Bacteria, and PBS control) with a $\mathrm{OD}_{600}$ of $0.239\left(1.91 \times 10^{8}\right.$ cells $\left.\mathrm{mL}^{-1}\right)$ were added on top of each gel-containing Transwell insert.

Cells were incubated $2.5 \mathrm{~h}$ at $37{ }^{\circ} \mathrm{C}$ at $5 \% \mathrm{CO}_{2}$ atmospheric concentration, and then both gel-containing Transwell inserts and cellcontaining wells were washed five times with PBS to remove the released Dox. Cell medium was refreshed with $1.5 \mathrm{~mL}$ of DMEM with Anti-Anti and $100 \mu \mathrm{L}$ added to the gel-containing inserts. It was incubated at $37^{\circ} \mathrm{C}$ at $5 \% \mathrm{CO}_{2}$ atmospheric concentration during $24 \mathrm{~h}$.

After $24 \mathrm{~h}$, the cytotoxic capacity of Dox was evaluated with Alamar Blue test. For that, cells supernatant was removed and cells were washed two times with PBS. Then, $1 \mathrm{~mL}$ of Alamar Blue solution (10\% in DMEM medium) was added to each well, and the gels were incubated at $37^{\circ} \mathrm{C}$ at $5 \% \mathrm{CO}_{2}$ atmospheric concentration during $2 \mathrm{~h}$. The fluorescence of supernatant was measured at $\lambda_{\mathrm{ex}}=570 \mathrm{~nm}$ and $\lambda_{\mathrm{em}}=585 \mathrm{~nm}$ using a microplate reader.

Immunogenic Assay: Peripheral blood was used to study IFN- $\gamma$ production into the main circulating immune cells in response to the bio-hybrid nanodevice. Briefly, mononuclear cells were isolated by density gradient centrifugation method by Ficoll (Histopaque-1077, Sigma-Aldrich). Then, $10^{6}$ cells per well in a 24 -well plate were seeded. One side, $0.5 \mu \mathrm{g} \mathrm{mL} \mathrm{m}^{-1}$ was added from a suspension of nanoparticles (MSN-PEG-DBCO) as positive control. On the other side, the same cellular concentration was used to be stimulated at scaling doses of bacteria alone (Bac) and the nanosystem (Bac-MSN) in presence of $2 \times 10^{-6} \mathrm{M} \mathrm{mL}^{-1}$ of Monensin (Sigma-Aldrich), a Golgi apparatus inhibitor for more than $5 \mathrm{~h}$. Finally, intracellular retention of IFN- $\gamma$ into circulating monocytes, T-cells, and B-cells by FACS following Beckton Dickson's protocol for intracellular staining with minor modifications (Figure S14, Supporting Information) was analyzed.
For immunophenotype analysis, immune cells were first stained for surface markers with allophycocyanin (APC)-conjugated anti-CD14 (clon МФР9), and R-phycoerythrin and cyanine dye Cy7 (PECy7)-conjugated anti-CD19 (clon 13-119) and allophycocyanin-H7 (APC)-conjugated anti-CD3 (clon SK7). For IFN- $\gamma$ detection, R-phycoerythrin (PE)conjugated anti-IFN- $\gamma$ (clon GIR-208) was used. All human monoclonal antibodies were purchased from BD Pharmingen, and anti-CD19 from Beckman Coulter. Cell acquisition was performed by flow cytometry (Canto-II, BD Biosciences) equipped with FACSDIVA software (BD, Biosciences) for multiparameter analysis of the data.

\section{Supporting Information}

Supporting Information is available from the Wiley Online Library or from the author.

\section{Acknowledgements}

This work was supported by European Research Council, ERC-2015-AdG (VERDI), Proposal No. 694160. The authors wish to thank the ICTS Centro Nacional de Microscopia Electrónica (Spain) and CAI Cytometer and Fluorescence microscopy of the Universidad Complutense de Madrid (Spain) for the assistance and Servier Medical art for the creative commons figures.

\section{Conflict of Interest}

The authors declare no conflict of interest.

\section{1} 2 3 4 5 6 7 8

\section{Author Contributions}

V.M.M. and E.A. have contributed equally to this work. The manuscript was written through contributions of all the authors. All the authors have given approval to the final version of the manuscript. The authors declare no competing financial interest.

\section{Keywords}

bacteria motors, mesoporous silica nanoparticles, nanocarriers tumor penetration, nanomedicine

Received: November 15, 2019 Revised: March 6, 2020 Published online:

[1] Y. Matsumura, H. Maeda, Cancer Res. 1986, 46, 6387.

[2] R. Cao-Milán, L. M. Liz-Marzán, Expert Opin. Drug Delivery 2014, $11,741$.

[3] M. Vallet-Regi, A. Rámila, R. P. Del Real, J. Pérez-Pariente, Chem. Mater. 2001, 13, 308.

[4] A. Riedinger, P. Guardia, A. Curcio, M. A. Garcia, R. Cingolani, L. Manna, T. Pellegrino, Nano Lett. 2013, 13, 2399.

[5] H. Oliveira, E. Pérez-Andrés, J. Thevenot, O. Sandre, E. Berra, S. Lecommandoux, J. Controlled Release 2013, 169, 165.

[6] M. Talelli, M. Barz, C. J. F. Rijcken, F. Kiessling, W. E. Hennink, T. Lammers, Nano Today 2015, 10, 93.

[7] P. P. Deshpande, S. Biswas, V. P. Torchilin, Nanomedicine 2013, 8, 1509. 
[8] M. R. Villegas, A. Baeza, M. Vallet-Regí, Molecules 2018, 23, 1008.

[9] C. He, J. Lu, W. Lin, J. Controlled Release 2015, 219, 224.

[10] H. Kobayashi, B. Turkbey, R. Watanabe, P. L. Choyke, Bioconjugate Chem. 2014, 25, 2093.

[11] V. J. Venditto, F. C. Szoka, Adv. Drug Delivery Rev. 2013, 65, 80.

[12] E. Blanco, H. Shen, M. Ferrari, Nat. Biotechnol. 2015, 33, 941.

[13] A. T. Florence, J. Controlled Release 2012, 164, 115.

[14] A. Parodi, S. G. Haddix, N. Taghipour, S. Scaria, F. Taraballi, A. Cevenini, I. K. Yazdi, C. Corbo, R. Palomba, S. Z. Khaled, J. O. Martinez, B. S. Brown, L. Isenhart, E. Tasciotti, ACS Nano 2014, 8, 9874.

[15] M. R. Villegas, A. Baeza, M. Vallet-Regí, ACS Appl. Mater. Interfaces 2015, 7, 24075

[16] M. R. Villegas, A. Baeza, A. Noureddine, P. N. Durfee, K. S. Butler, J. O. Agola, C. J. Brinker, M. Vallet-Regí, Chem. Mater. 2018, 30, 112.

[17] R. K. Jain, T. Stylianopoulos, Nat. Rev. Clin. Oncol. 2010, 7, 653.

[18] J. W. Nichols, Y. H. Bae, J. Controlled Release 2014, 190, 451.

[19] M. Sitti, B. Mostaghaci, B.-W. Park, O. Yasa, Z. Hosseinidoust, A. V. Singh, Adv. Drug Delivery Rev. 2016, 106, 27.

[20] J. L. Paris, P. D. La Torre, M. Manzano, M. V. Cabañas, A. I. Flores, M. Vallet-Regí, Acta Biomater. 2016, 33, 275.

[21] S. Taherkhani, M. Mohammadi, J. Daoud, S. Martel, M. Tabrizian, ACS Nano 2014, 8, 5049.

[22] S. Song, M. S. Vuai, M. Zhong, Infect. Agents Cancer 2018, 13, 9.

[23] O. Felfoul, M. Mohammadi, S. Taherkhani, D. De Lanauze, Y. Zhong Xu, D. Loghin, S. Essa, S. Jancik, D. Houle, M. Lafleur, L. Gaboury, M. Tabrizian, N. Kaou, M. Atkin, T. Vuong, G. Batist, N. Beauchemin, D. Radzioch, S. Martel, Nat. Nanotechnol. 2016, 11, 941.

[24] N. S. Forbes, Nat. Rev. Cancer 2010, 10, 785.

[25] S. Xie, L. Zhao, X. Song, M. Tang, C. Mo, X. Li, J. Controlled Release 2017, 268, 390

[26] S. Zhou, C. Gravekamp, D. Bermudes, K. Liu, Nat. Rev. Cancer 2018, $18,727$.
[27] S. Xie, M. Chen, X. Song, Z. Zhang, Z. Zhang, Z. Chen, X. Li, Acta 1 Biomater. 2018, 78, 198.

[28] J.-W. Yoo, D. J. Irvine, D. E. Discher, S. Mitragotri, Nat. Rev. Drug Discovery 2011, 10, 521.

[29] F. Chen, Z. Zang, Z. Chen, L. Cui, Z. Chang, A. Ma, T. Yin, R. Liang, 5 Y. Han, Z. Wu, M. Zheng, C. Liu, L. Cai, Biomaterials 2019, 214, 119226.

[30] S. B. Suh, A. Jo, M. A. Traore, Y. Zhan, S. L. Coutermarsh-Ott, 7 V. M. Ringel-Scaia, I. C. Allen, R. M. Davis, B. Behkam, Adv. Sci. 8 2019, 6, 1801309.

[31] J. Lu, M. Liong, Z. Li, J. I. Zink, F. Tamanoi, Small 2010, 6, 1794.

[32] M. S. VanNieuwenhze, H. V. Hughes, M. A. de Pedro, P. J. Brown, 11 F. Cava, E. Kuru, E. Hall, S. Tekkam, Y. V. Brun, Angew. Chem., Int. 12 Ed. 2012, 51, 12519.

[33] E. M. Sletten, C. R. Bertozzi, Angew. Chem., Int. Ed. 2009, 48, 6974.

[34] J. A. Prescher, C. R. Bertozzi, Nat. Chem. Biol. 2005, 1, 13.

[35] P. V. Chang, J. A. Prescher, E. M. Sletten, J. M. Baskin, I. A. Miller, N. J. Agard, A. Lo, C. R. Bertozzi, Proc. Natl. Acad. Sci. USA 2010 107, 1821.

[36] E. Guisasola, A. Baeza, M. Talelli, D. Arcos, M. Moros, 18 J. M. De La Fuente, M. Vallet-Regí, Langmuir 2015, 31, 12777.

[37] J. L. Paris, M. Colilla, I. Izquierdo-Barba, M. Manzano, 20 M. Vallet-Regí, J. Mater. Sci. 2017, 52, 8761.

[38] W. R. Algar, D. E. Prasuhn, M. H. Stewart, T. L. Jennings, 22 J. B. Blanco-Canosa, P. E. Dawson, I. L. Medintz, Bioconjugate 23 Chem. 2011, 22, 825.

[39] H. Koo, S. Lee J. H. Na, S. H. Kim, S. K. Hahn, K. Choi, I. C. Kwon, S. Y. Jeong, K. Kim, Angew. Chem., Int. Ed. 2012, 51, 11836.

[40] A. Sahari, M. A. Traore, B. E. Scharf, B. Behkam, Biomed. Micro- 26 devices 2014, 16, 717.

[41] H. W. Child, P. A. Del Pino, J. M. De La Fuente, A. S. Hursthouse, 28 D. Stirling, M. Mullen, G. M. McPhee, C. Nixon, V. Jayawarna, 29 C. C. Berry, ACS Nano 2011, 5, 7910.

[42] J. Shen, Q. He, Y. Gao, J. Shi, Y. Li, Nanoscale 2011, 3, 4314.

[43] F. Danhier, O. Feron, V. Préat, J. Controlled Release 2010, 148, 135. 


\section{Reprint Order Form}

Charges for Reprints in Euro (excl. VAT), prices are subject to change. Minimum order 50 copies.

\begin{tabular}{|c|c|c|c|c|c|c|}
\hline No. of pages & $\begin{array}{c}\mathbf{5 0} \\
\text { copies }\end{array}$ & $\begin{array}{c}100 \\
\text { copies }\end{array}$ & $\begin{array}{c}150 \\
\text { copies }\end{array}$ & $\begin{array}{c}200 \\
\text { copies }\end{array}$ & $\begin{array}{c}300 \\
\text { copies }\end{array}$ & $\begin{array}{c}\mathbf{5 0 0} \\
\text { copies }\end{array}$ \\
\hline $1-4$ & $345,-$ & $395,-$ & $425,-$ & $445,-$ & $548,-$ & $752,-$ \\
\hline $5-8$ & $490,-$ & $573,-$ & $608,-$ & $636,-$ & $784,-$ & $1077,-$ \\
\hline $9-12$ & $640,-$ & $739,-$ & $786,-$ & $824,-$ & $1016,-$ & $1396,-$ \\
\hline $13-16$ & $780,-$ & $900,-$ & $958,-$ & $1004,-$ & $1237,-$ & $1701,-$ \\
\hline $17-20$ & $930,-$ & $1070,-$ & $1138,-$ & $1196,-$ & $1489,-$ & $2022,-$ \\
\hline $\begin{array}{l}\text { every additional } \\
4 \text { pages }\end{array}$ & $147,-$ & $169,-$ & $175,-$ & $188,-$ & $231,-$ & $315,-$ \\
\hline
\end{tabular}

Please send me send bill me for

no. of reprints

high-resolution PDF file (330 Euro excl. VAT)

E-mail address:

* Special Offer:

If you order 200 or more reprints you will get a PDF file for half price.

Please note: It is not permitted to present the PDF file on the internet or on company homepages.

Cover Posters (prices excl. VAT)

Posters of published covers are available in two sizes: DinA2 42 x $60 \mathrm{~cm} / 17$ x 24in (one copy: 39 Euro)

DinA1 $60 \times 84 \mathrm{~cm} / 24$ x 33in (one copy: 49 Euro)

Postage for shipping (prices excl. VAT)

overseas +25 Euro

within Europe +15 Euro
Email: advmatinterfaces@wiley-vch.de

Manuscript No.:

Customer No.: (if available)

Purchase Order No.:

Author:

Information regarding VAT: The charges for publication of cover pictures /reprints/issues/poster/Video abstracts/are considered to be "supply of services" and therefore subject to German VAT. However, if you are an institutional customer outside Germany, the tax can be waived if you provide us with the valid VAT number of your company. Non-EU customers may have a VAT number starting with "EU" instead of their country code, if they are registered with the EU tax authorities. If you do not have a valid EU VAT number and you are a taxable person doing business in a non-EU country, please provide a certification from your local tax authorities confirming that you are a taxable person under local tax law. Please note that the certification must confirm that you are a taxable person and are conducting an economic activity in your country. Note: certifications confirming that you are a taxexempt legal body (non-profit organization, public body, school, political party, etc.) in your country do not exempt you from paying German VAT.

VAT number:

Mail reprints / copies of the issue to:

Send bill to:

I will pay by bank transfer

I will pay by credit card

VISA, Mastercard and AMERICAN EXPRESS

For your security please use this link (Credit Card Token Generator) to create a secure code Credit Card Token and include this number in the form instead of the credit card data. Click here: https://www.wiley-vch.de/editorial production/index.php CREDIT CARD TOKEN NUMBER 